\title{
Effects of Smoke-Water on Photosynthetic Characteristics of Isatis indigotica Seedlings
}

\author{
Jie Zhou ${ }^{1,2, *}$, Lei Fang ${ }^{2, *}$, Xiao Wang ${ }^{2}$, Lanping Guo ${ }^{1}$ \& Luqi Huang ${ }^{1}$ \\ ${ }^{1}$ Institute of Chinese Materia Medica, China Academy of Chinese Medical Sciences, Beijing, China \\ ${ }^{2}$ Shandong Analysis and Test Center, Shandong Academy of Sciences, Jinan, China \\ *These authors contributed equally to this work. \\ Correspondence: Luqi Huang and Lanping Guo, Institute of Chinese Materia Medica, China Academy of \\ Chinese Medical Sciences, Beijing, China. Tel: 86-010-64011944. E-mail: glp01@126.com and \\ zhoujie8761@126.com
}

Received: August 29, 2012 Accepted: October 28, 2012 Online Published: December 10, 2012

doi:10.5539/sar.v2n2p24 URL: http://dx.doi.org/10.5539/sar.v2n2p24

\begin{abstract}
Smoke-water (SW) had been reported to improve the growth of Isatis indigotica, a Chinese medicinal plant. However, there were very few reports on the mechanism of smoke-water improving plant growth. In this study the effects of smoke-water on the photosynthetic characteristics of I. indigotica seedlings were investigated for the purpose of understanding the mechanism behind this improved plant growth. The results showed that net photosynthetic rate $\left(P_{n}\right)$ was increased by smoke-water, reaching a maximum on 15,5 and $15 \mathrm{~d}$ after treatment with smoke-water at dilutions of 1:500, 1:1000 and 1:2000 respectively. Transpiration rate $\left(T_{r}\right)$ and stomatal conductance $\left(G_{s}\right)$ both showed similar trends to $P_{n}$, however, intercellular $\mathrm{CO}_{2}$ concentration $\left(C_{i}\right)$ was decreased with smoke-water treatment. The $\mathrm{F}_{\mathrm{v}} / \mathrm{F}_{\mathrm{m}}$ was not significantly influenced by smoke-water treatment. The $\Phi$ PSII was markedly promoted with the application of smoke-water (1:1000) compared with the control and the coefficient of photochemical quenching (qP) showed a similar trend to DPSII. However the coefficient of non-photochemical quenching of chlorophyll (NPQ) was decreased with treatment of smoke-water. These findings indicate that smoke-water treatment induce an increase in photosynthesis and suggest the main factors leading to this might be the improved stomatal conductance and the enhanced level of the photochemical efficiency of PSII in leaves.
\end{abstract}

Keywords: Isatis indigotica, smoke-water, gas-exchange, chlorophyll fluorescence

\section{Introduction}

It has been reported that smoke plays an important role in many aspects of plant biology such as seed germination, plant growth and flowering (Kulkarni, Ascough, \& Van Staden, 2008). Smoke treatments stimulate seed germination of more than 1200 species (Brown \& Botha, 2004; Dixon, Merritt, Flematti, \& Ghisalberti, 2009), and also markedly improve plant growth in certain cases. It's been demonstrated that soaking in smoke-water enhance the vigour of Zea mays seedling (Sparg, Kulkarni, \& Van Staden, 2006). The yield of crop has been enhanced with the treatment of smoke-water, including okra, tomato and onion (Kulkarni, Ascough, \& Van Staden, 2007; Kulkarni, Ascough, \& Van Staden, 2008; Kulkarni, Ascough, Verschaeve, Baeten, Arruda, \& Van Staden, 2010; Aremu, Bairu, Finnie, \& Van Staden, 2012). The great potential of smoke treatments for the use in horticulture and agriculture has been shown. However few studies on the mechanism of how smoke-water improving plant growth have been reported.

Isatis indigotica is one of the most popular Traditional Chinese medicine (TCM), which plays an important role in keeping people's health, and is used as anti-leukemia, antipyretic and anti-influenza agents (Liu, Huang, Lin, Wu, \& Lin, 2005; Kunikata, Tatefuji, Aga, Iwaki, Ikeda, \& Kurimoto, 2000; Mak, Leung, Wei, Shena, Wonga, Leungd, \& Funge, 2004). Due to its medicinal importance, the demand for this herb has improved the cultivation practices of I. Indigotica. Our research group has reported that the growth of I. indigotica seedlings was improved by the treatment with smoke-water (Zhou, Van Staden, Guo, \& Huang, 2011). However, few studies on the mechanism of smoke-water improving the growth of seedlings have been previously reported. Photosynthetic characteristics are important indicators which reflect the accumulation of plant biomass. Thus, examining the 
effects of smoke-water on the parameters of photosynthetic characteristics will lead to a greater understanding of the mechanism of smoke-water in improving plant growth. Therefore this study was carried out to explore the mechanism of how smoke-water improves plant growth by examining the photosynthetic gas-exchange characteristics and chlorophyll fluorescence for the purpose of providing a theoretical basis for the application of smoke-water in the cultivation of medicinal plants.

\section{Materials and Methods}

Seeds of $I$. indigotica were sown in a mixture of garden soil and river sand and incubated at $25 \pm 1{ }^{\circ} \mathrm{C}$. After the third leaf developed uniform seedlings were transplanted into plastic pots filled with quartz sand and half-strength Hoagland's solution (HS) was used as growth medium (Zhou, Van Staden, Guo, \& Huang, 2011). The seedlings were used for trial after emergence of the sixth leaf, HS containing smoke-water with dilutions of 1:500, 1:1000 and 1:2000 were applied and an equivalent amount of HS was used as control (100 ml per pot). There were 10 replicates for each treatment and the quartz sand was re-moistened with $50 \mathrm{ml}$ HS once a week. Seedlings were incubated at $25 / 22^{\circ} \mathrm{C}$ (day/night) under a $14 \mathrm{~h}$ photoperiod with $280 \mu \mathrm{mol} / \mathrm{m}^{2} \cdot \mathrm{s}$ at a relative humidity of $65 \%$. Smoke-water was prepared as described by Van Staden et al. (2004), Platanus orientalis and Platanus occidentalis were used as plant material.

Gas-exchange parameters and chlorophyll fluorescence of seedlings were determined at 9:00 am to 11:30 am on $0,1,3,5,7,11$ and $15 \mathrm{~d}$ following treatment. Photosynthesis system (Li-6400, USA) was used to measure the $P_{\mathrm{n}}$, $T_{\mathrm{r}}, C_{\mathrm{i}}$ and $G_{\mathrm{s}}$ at leaf temperature of $25^{\circ} \mathrm{C}$ and constant $\mathrm{CO}_{2}$ level of $380 \mu \mathrm{mol} \mathrm{mol}^{-1}$. Chlorophyll fluorescence was measured using a portable chlorophyll fluorometer (Opti-Science, USA). Minimum fluorescence $\left(\mathrm{F}_{\mathrm{o}}\right)$ and maximum fluorescence $\left(\mathrm{F}_{\mathrm{m}}\right)$ were obtained by imposing a 1s saturating flash to the leaf. The steady-state fluorescence $\left(\mathrm{F}_{\mathrm{s}}\right)$ was obtained on light-acclimated leaf by imposing the same saturating flash. A second saturating pulse of white light was imposed to determine the maximum fluorescence level $\left(\mathrm{F}_{\mathrm{m}}{ }^{\prime}\right)$ in the light-adapted state. The actinic light was turned off and the minimal fluorescence level in the light-adapted state $\left(\mathrm{F}_{\mathrm{o}}{ }^{\prime}\right)$ was obtained by illuminating the leaf with far-red light. The maximum potential photochemical efficiency of PSII was calculated as $F_{v} / F_{m}=\left(F_{m}-F_{o}\right) / F_{m}$; the actual efficiency of PSII (ФPSII) was expressed as ФPSII = $\left(\mathrm{F}_{\mathrm{m}}{ }^{\prime}-\mathrm{F}_{\mathrm{s}}\right) / \mathrm{F}_{\mathrm{m}}{ }^{\prime}$ (Genty, Briantais, \& Baker, 1989); the coefficient of photochemical quenching (qP) and the coefficient of non-photochemical quenching of chlorophyll (NPQ) were estimated as $q P=\left(\mathrm{F}_{\mathrm{m}}{ }^{\prime}-\mathrm{F}_{\mathrm{s}}\right) /\left(\mathrm{F}_{\mathrm{m}}{ }^{\prime}-\mathrm{F}_{\mathrm{o}}{ }^{\prime}\right)$, $\mathrm{NPQ}=\mathrm{F}_{\mathrm{m}} / \mathrm{F}_{\mathrm{m}}{ }^{\prime}-1$ (Baker, 2008; Demmig, Adams, Barker, Logan, \& Bowling, 1996).

Statistical analysis was conducted using SPSS 13.0 software. Data were subjected to one-way analysis of variance (ANOVA) and differences were considered significant at $p<0.05$.

\section{Results and Discussion}

As shown in Table $1, P_{\mathrm{n}}$ of the seedlings was enhanced and reached the maximum values with the treatment of smoke-water at 1:500, 1:1000 and 1:2000 on 15, 5 and $15 \mathrm{~d}$ after treatment, which were estimated to be $14.34 \%$, $17.14 \%$ and $9.63 \%$ higher than the control, respectively. $T_{\mathrm{r}}$ and $G_{\mathrm{s}}$ showed similar trends to $P_{\mathrm{n}}$. $T_{\mathrm{r}}$ for smoke-water at 1:500 and 1:1000 was significantly improved by smoke-water treatment at 1:500 and 1:1000 on $3,5,7,11$ and 15 d. $C_{\mathrm{i}}$ was decreased by the treatment of smoke-water, which reached a minimum on days 15 , 11 , and 15 after the treatment with smoke-water at dilutions of 1:500, 1:1000, and 1:2000, respectively. Enhancing gas exchange, photochemical activities and $\mathrm{CO}_{2}$ fixation can induce an increase in photosynthesis. In this study treatment with smoke-water, especially at the dilution of 1:1000, increased of $P_{n}, T_{r}$ and $G_{s}$ of $I$. indigotica seedlings, which suggests that the treatment of smoke-water likely could enhance the stomatal opening. Thus the induction of stomatal opening by smoke-water treatment may be one of the mechanisms for increasing in photosynthesis observed.

The effects of smoke-water on chlorophyll fluorescence parameters of I. indigotica seedlings are presented in Figure 1. The value of $F_{v} / F_{m}$ was not enhanced by smoke-water treatment (Figure 1A). The $\Phi$ PSII was markedly enhanced by smoke-water at 1:1000 compared to the control (Figure 1B). Maximum values of $\Phi$ PSII for smoke-water at 1:1000 were recorded on $1 \mathrm{~d}$ after treatment. The qP showed a similar trend to the ФPSII, however, the NPQ was markedly decreased by the treatment of smoke-water (Figure 1D). Chlorophyll fluorescence measurements are regarded as a sensitive diagnostic technique for determining the effects of environmental factors on photosynthesis (Yang, Yi, \& Prasad, 2009). Photochemical reactions, fluorescence (non-photochemical) and heat dissipation are three ways by which the light energy absorbed by chlorophyll molecules is consumed. $\mathrm{F}_{\mathrm{v}} / \mathrm{F}_{\mathrm{m}}$, ,PSII, and $\mathrm{qP}$ are used to describe photochemical-quenching parameters, while NPQ for non-photochemical-quenching parameter (Genty, Briantais, \& Baker, 1989). In this study ФPSII, qP and NPQ fluctuated simultaneously, suggesting the absorbed energy was redistributed in the different ways. ФPSII and qP were increased by smoke-water treatment, indicating that much of the energy is used for the 
photosynthetic electron transfer. This implies that smoke-water treatment enhances $P_{n}$ by exploiting the harvested light energy more efficiently in photosynthesis.

Table 1. Effects of smoke-water on $P_{\mathrm{n}}, T_{r}, C_{\mathrm{i}}$, and $G_{\mathrm{s}}$ of $I$. indigotica seedlings on $0,1,3,5,7,11$ and $15 \mathrm{~d}$ after treatment (mean $\pm \mathrm{SD}$ ). Different letters indicate significant differences at $p<0.05$ when compared with the control according to the Duncan's multiple range test

\begin{tabular}{|c|c|c|c|c|c|c|c|}
\hline$\overline{P_{n}\left(\mu \mathrm{m} \cdot \mathrm{m}^{-2} \mathrm{~s}^{-1}\right)}$ & Od & 1d & 3d & $5 d$ & $7 d$ & 11d & 15d \\
\hline Control & $4.98 \pm 0.19 \mathrm{a}$ & $4.80 \pm 0.16 \mathrm{a}$ & $4.82 \pm 0.13 b$ & $4.90 \pm 0.18 c$ & $4.89 \pm 0.25 \mathrm{c}$ & $5.03 \pm 0.20 \mathrm{~b}$ & $5.09 \pm 0.19 \mathrm{c}$ \\
\hline SW (1:500) & $5.02 \pm 0.15 \mathrm{a}$ & $4.98 \pm 0.17 \mathrm{a}$ & $5.09 \pm 0.14 \mathrm{a}$ & $5.55 \pm 0.13 b$ & $5.40 \pm 0.18 \mathrm{a}$ & $5.10 \pm 0.10 \mathrm{~b}$ & $5.82 \pm 0.16 \mathrm{a}$ \\
\hline SW (1:1000) & $5.01 \pm 0.23 \mathrm{a}$ & $4.90 \pm 0.14 \mathrm{a}$ & $4.98 \pm 0.18 b$ & $5.74 \pm 0.15 \mathrm{a}$ & $5.71 \pm 0.24 \mathrm{a}$ & $5.64 \pm 0.21 \mathrm{a}$ & $5.71 \pm 0.13 b$ \\
\hline SW (1:2000) & $5.00 \pm 0.18 \mathrm{a}$ & $4.77 \pm 0.19 \mathrm{a}$ & $4.79 \pm 0.16 \mathrm{~b}$ & $5.05 \pm 0.14 \mathrm{c}$ & $5.07 \pm 0.13 b$ & $5.24 \pm 0.25 \mathrm{~b}$ & $5.58 \pm 0.23 b$ \\
\hline$T_{r}\left(\mathbf{m m} \cdot \mathbf{m}^{-2} \mathbf{s}^{-1}\right)$ & Od & 1d & 3d & $5 d$ & $7 d$ & 11d & $15 d$ \\
\hline Control & $0.87 \pm 0.05 \mathrm{a}$ & $0.84 \pm 0.08 \mathrm{a}$ & $0.93 \pm 0.13 b$ & $0.95 \pm 0.17 \mathrm{~b}$ & $0.87 \pm 0.19 \mathrm{c}$ & $0.81 \pm 0.15 b$ & $0.92 \pm 0.14 \mathrm{~b}$ \\
\hline SW (1:500) & $0.81 \pm 0.03 \mathrm{a}$ & $0.87 \pm 0.08 \mathrm{a}$ & $1.48 \pm 0.11 \mathrm{a}$ & $1.15 \pm 0.11 \mathrm{a}$ & $1.11 \pm 0.17 \mathrm{a}$ & $1.31 \pm 0.28 \mathrm{a}$ & $1.15 \pm 0.17 \mathrm{a}$ \\
\hline SW (1:1000) & $0.89 \pm 0.02 \mathrm{a}$ & $0.91 \pm 0.09 \mathrm{a}$ & $1.02 \pm 0.12 \mathrm{~b}$ & $1.30 \pm 0.25 \mathrm{a}$ & $1.26 \pm 0.06 \mathrm{a}$ & $1.34 \pm 0.25 \mathrm{a}$ & $1.12 \pm 0.16 \mathrm{a}$ \\
\hline SW (1:2000) & $0.86 \pm 0.03 \mathrm{a}$ & $0.80 \pm 0.09 \mathrm{a}$ & $0.92 \pm 0.14 \mathrm{~b}$ & $0.83 \pm 0.09 b$ & $1.05 \pm 0.09 \mathrm{~b}$ & $0.82 \pm 0.35 b$ & $0.81 \pm 0.23 b$ \\
\hline$C_{i}\left(\mu \mathrm{mol} \cdot \mathrm{mol}^{-1}\right)$ & Od & 1d & 3d & $5 d$ & $7 d$ & 11d & 15d \\
\hline Control & $251.00 \pm 12.83 a$ & $240.83 \pm 32.10 \mathrm{a}$ & $253.17 \pm 27.47 \mathrm{a}$ & $254.13 \pm 30.01 \mathrm{a}$ & $245.83 \pm 15.7 \mathrm{a} 2$ & $256.17 \pm 22.13 \mathrm{a} 2$ & $249.17 \pm 27.53 a$ \\
\hline SW (1:500) & $248.67 \pm 31.82 \mathrm{a}$ & $232.50 \pm 25.32 a$ & $209.17 \pm 33.05 b$ & $218.33 \pm 25.93 b$ & $216.67 \pm 26.6 \mathrm{~b} 2$ & $212.03 \pm 35.62 \mathrm{~b} 2$ & $207.83 \pm 34.20 \mathrm{~b}$ \\
\hline SW $(1: 1000)$ & $244.83 \pm 26.48 \mathrm{a}$ & $248.17 \pm 23.18 \mathrm{a}$ & $225.33 \pm 23.04 b$ & $213.80 \pm 23.57 b$ & $217.00 \pm 27.3 b 2$ & $212.22 \pm 21.01 \mathrm{~b} 2$ & $212.67 \pm 31.35 b$ \\
\hline SW (1:2000) & $243.17 \pm 27.19 \mathrm{a}$ & $242.50 \pm 23.45 \mathrm{a}$ & $225.50 \pm 25.63 \mathrm{~b}$ & $245.30 \pm 28.05 \mathrm{a}$ & $221.83 \pm 23.9 \mathrm{~b} 2$ & $247.83 \pm 14.39 \mathrm{a} 2$ & $217.67 \pm 21.62 b$ \\
\hline$G_{s}\left(\mathrm{~mol} \cdot \mathrm{m}^{-2} \mathrm{~s}^{-1}\right)$ & od & 1d & $3 d$ & $5 d$ & $7 d$ & 11d & $15 d$ \\
\hline Control & $0.05 \pm 0.007 \mathrm{a}$ & $0.04 \pm 0.002 \mathrm{a}$ & $0.04 \pm 0.003 \mathrm{c}$ & $0.04 \pm 0.002 \mathrm{~b}$ & $0.04 \pm 0.008 \mathrm{~b}$ & $0.05 \pm 0.010 \mathrm{~b}$ & $0.05 \pm 0.010 \mathrm{~b}$ \\
\hline SW (1:500) & $0.05 \pm 0.002 \mathrm{a}$ & $0.04 \pm 0.001 \mathrm{a}$ & $0.06 \pm 0.009 \mathrm{a}$ & $0.06 \pm 0.008 \mathrm{a}$ & $0.05 \pm 0.009 \mathrm{a}$ & $0.06 \pm 0.008 \mathrm{a}$ & $0.06 \pm 0.017 \mathrm{a}$ \\
\hline SW (1:1000) & $0.05 \pm 0.009 \mathrm{a}$ & $0.05 \pm 0.007 \mathrm{a}$ & $0.06 \pm 0.007 \mathrm{a}$ & $0.06 \pm 0.005 \mathrm{a}$ & $0.06 \pm 0.016 \mathrm{a}$ & $0.07 \pm 0.019 \mathrm{a}$ & $0.05 \pm 0.008 \mathrm{a}$ \\
\hline SW (1:2000) & $0.04 \pm 0.002 \mathrm{a}$ & $0.05 \pm 0.005 \mathrm{a}$ & $0.05 \pm 0.005 b$ & $0.06 \pm 0.010 \mathrm{a}$ & $0.04 \pm 0.015 b$ & $0.05 \pm 0.010 \mathrm{~b}$ & $0.05 \pm 0.009 b$ \\
\hline
\end{tabular}



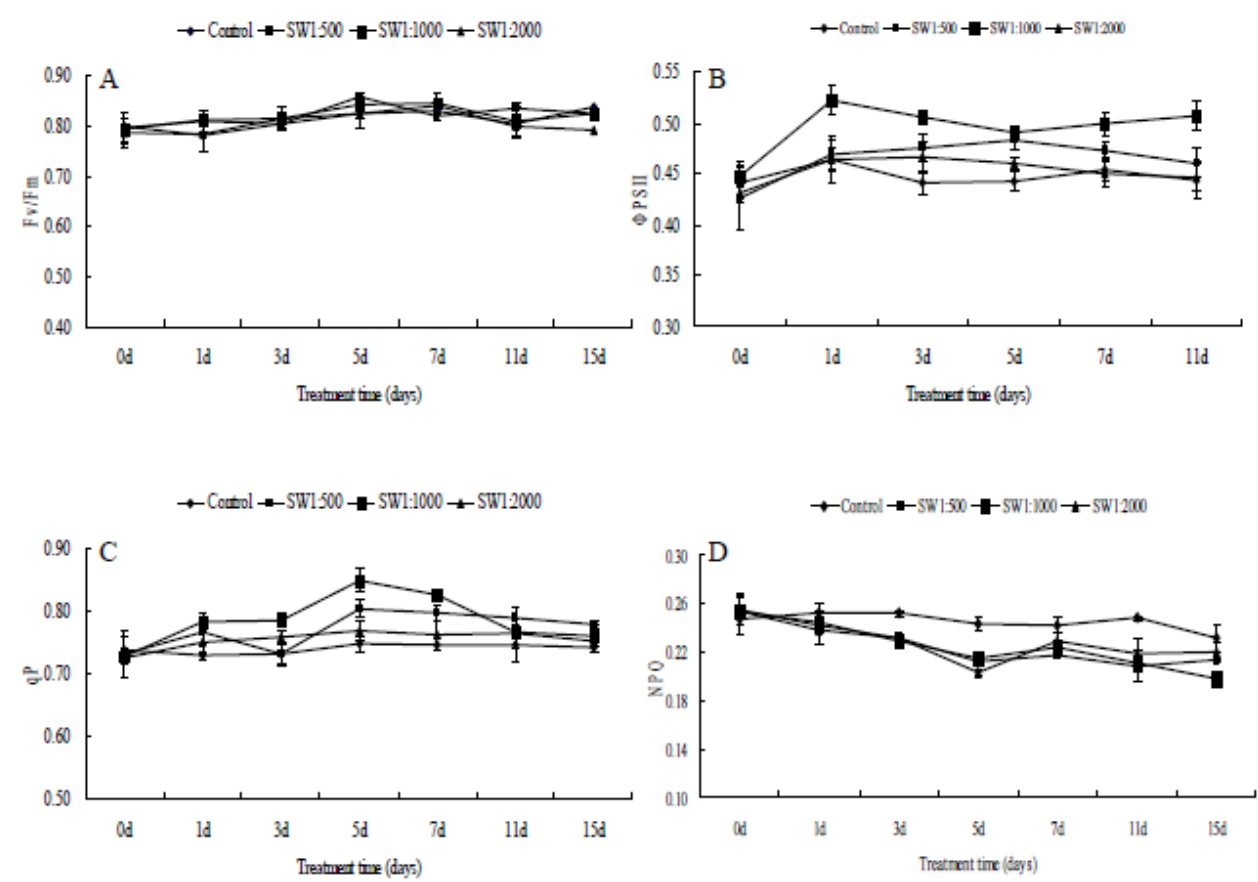

Figure 1. Effects of smoke-water on $\mathrm{F}_{\mathrm{v}} / \mathrm{F}_{\mathrm{m}}(\mathrm{A})$, ФPSII (B), $\mathrm{qP}(\mathrm{C})$, and NPQ (D) of I. indigotica seedlings on 0d, $1 \mathrm{~d}, 3 \mathrm{~d}, 5 \mathrm{~d}, 7 \mathrm{~d}, 11 \mathrm{~d}$ and $15 \mathrm{~d}$ after treatment

In conclusion, the photosynthesis of $I$. indigotica seedlings could be enhanced with the treatment of smoke-water. Smoke-water enhances $P_{n}$ by inducing of stomatal opening and exploiting the harvested light energy more efficiently in photosynthesis.

\section{Acknowledgments}

This work was supported by the China and SA Co-operative Project (No. 2009DFA31660), the National Natural Science Foundation of China (No. 81130070, 81072989, 21202094), the Research Projects of State Administration of Traditional Chinese Medicine of China (No. 201107009), Natural Science Foundation of Shandong Province ( ZR2012HQ020), the Important National Science and Technology Specific Projects program (No. 2009ZX09502-026, 2009ZX09301-005), the Research Projects of Chinese Medical Sciences (No. ZZ20090302) and the Science and Technology Program of ShanDong Acadamy of Sciences. Thanks to Dr. M. E. Light from University of KwaZulu-Natal, South Africa for English language editing of the manuscript.

\section{References}

Aremu, A. O., Bairu, M. W., Finnie, J. F., \& Van Staden, J. (2012). Stimulatory role of smoke-water and karrikinolide on the photosynthetic pigment and phenolic contents of micropropagated 'Williams' bananas. Plant Growth Regulation, 67, 271-279. http://dx.doi.org/10.1007/s10725-012-9685-3

Baker, N. R. (2008). Chlorophyll Fluorescence: A Probe of Photosynthesis In Vivo. Annual Review of Plant Biology, 59, 89-113. http://dx.doi.org/10.1146/annurev.arplant.59.032607.092759

Brown, N. A. C., \& Botha, P. A. (2004). Smoke seed germination studies and a guide to seed propagation of plants from the major families of the Cape Floristic Region. South Africa. South African Journal of Botany, $70,559-581$.

Demmig, A. B., Adams, W. W. III., Barker, D. H., Logan, B. A., \& Bowling, D. R. (1996). Using chlorophyll fluorescence to assess the fraction of absorbed light allocated to thermal dissipation of excess excitation. Physiologia Plantarum, 98, 253-264. http://dx.doi.org/10.1034/j.1399-3054.1996.980206.x

Dixon, K. W., Merritt, D. J., Flematti, G. R., \& Ghisalberti, E. L. (2009). Karrikinolide-a phytoreactive compound derived from smoke with applications in horticulture, ecological restoration and agriculture. Acta Horticulturae, 813, 155-170.

Genty, B., Briantais, J. M., \& Baker, N. R. (1989). The relationship between the quantum yield of photosynthetic 
electron transport and quenching of chlorophyll fluorescence. Biochimica et Biophysica Acta, 990, 87-92. http://dx.doi.org/10.1016/S0304-4165(89)80016-9

Kulkarni, M. G., Ascough, G. D., \& Van Staden, J. (2007). Effect of foliar applications of smoke-water and a smoke-isolated butenolide on seedling growth of okra and tomato. HortScience, 42, 179-182.

Kulkarni, M. G., Ascough, G. D., \& Van Staden, J. (2008). Smoke-water and a smoke isolated butenolide improve growth and yield of tomatoes under greenhouse conditions. HortTechnology, 18, 449-454.

Kulkarni, M. G., Ascough, G. D., Verschaeve, L., Baeten, K., Arruda, M. P., \& Van Staden, J. (2010). Effect of smoke-water and a smoke-isolated butenolide on the growth and genotoxicity of commercial onion. HortScience, 124, 434-439.

Kunikata, T., Tatefuji, T., Aga, H., Iwaki, K., Ikeda, M., \& Kurimoto, M. (2000). Indirubin inhibits inflammatory reactions in delayed-type hypersensitivity. European Journal of Pharmacology, 410, 93-100. http://dx.doi.org/10.1016/S0014-2999(00)00879-7

Liu, J. J., Huang, R. W., Lin, D. J., Wu, X. Y., \& Lin, Q. (2005). Antiproliferation effects of ponicidin on human myeloid leukemia cells in vitro. Oncology Reports, 13, 653-657.

Mak, N. K., Leung, C. Y., Wei, X. Y., Shena, X. L., Wonga, R.N. S., Leungd, K. N., \& Funge, M. C. (2004). Inhibition of RANTES expression by indirubin in influenza virus infected human bronchial epithelial cells. Biochemical Pharmacology, 67, 167-174. http://dx.doi.org/10.1016/j.bcp.2003.08.020

Sparg, S. G., Kulkarni, M. G., \& Van Staden, J. (2006). Aerosol smoke and smoke-water stimulation of seedling vigor of a commercial maize cultivar. Crop Science, 46, 1336-1340. http://dx.doi.org/10.2135/cropsci2005.07-0324

Van Staden, J., Jäger, A. K., Light, M. E., \& Burger, B. V. (2004). Isolation of the major germination cue from plant-derived smoke. South African Journal of Botany, 70, 654-659.

Yang, Y. Q., Yi, X. F., \& Prasad, P. (2009). Response of photosynthesis and chlorophyll fluorescence quenching to leaf dichotocarpism in Ligustrum vicaryi, an ornamental herb. Photosynthetica, 47(1), 137-140. http://dx.doi.org/10.1007/s11099-009-0022-7

Zhou, J., Van Staden, J., Guo, L. P., \& Huang, L. Q. (2011). Smoke-water improves shoot growth and indigo accumulation in shoots of Isatis indigotica seedlings. South African Journal of Botany, 77, 787-789. http://dx.doi.org/10.1016/j.sajb.2011.02.004 